\title{
Notes on the Accidental Introduction of Umbonia crassicornis (Amyot \& Serville)-(Hemiptera: Membracidae) into Puerto Rico and its Control'
}

\author{
Luis F. Martorell and José C. García-Tudurí2
}

\section{INTRODUCTION}

A series of treehoppers or membracids was brought to the authors for identification during May 1972 by Mrs. Sonia Goicoechea, an Agronomist in the Division of Ornamentals, Department of Public Works, Commonwealth of Puerto Rico. The species was one unknown to them at the time. The specimens had been collected on "guamá americano," Pithecellobium dulce, growing in the proximity of the Public Works building at Avenida de Diego, in Santurce.

A survey made in May at the site of collection revealed most "guamá americano" trees there and in adjacent areas were heavily infested by the membracid. A few days later, also in May, another quick survey revealed that Pithecellobium trees were similarly attacked in the vicinity of the International Airport at Isla Verde, Carolina; in the Miramar and Condado areas at Santurce; and at the San Jose Housing Project, in Hato Rey. Further surveys conducted during the summer of 1972 showed the species already established in the areas of Río Piedras, Caparra Heights and Bayamón, more than 10 miles south and west of the original collection site. During November 1972 the pest was recorded on the same host in Mayagüez, some $\$ 0$ miles from Santurce, on the west coast of Puerto Rico.

\section{TAXONOMY AND GEOG:APHIC DISTRIBUTION}

This treehopper species has been identificd as Umbonia crassicornis (Amyot \& Serville) by Dr. Richard C. Frocschner, Associate Curator of the Department of Entomology, U.S. National Museum (Smithsonian Institution), Washington, D.C. This specics has not been reported officially from Puerto Rico and is thus assumed to be a newly introduced pest.

Dr. José A. Ramos (8), Entomologist and Director of Graduate Studies, Mayagüez Campus, University of Puerto Rico, in a personal communication reports that his son Stuart Ramos collected a live female specimen March 26, 1972 inside an airplanc ready for departure from San Juan International Airport to Santo Domingo, Dominican Republic. This con-

1 Manuscript submitted to Ieditorial Board February 14, 1973.

2 Entomologist and Assistant Entomologist, respectively, Agricultural Experiment Station, Mayagüez Campus, University of Puerto Rico Río, Piedras, P. R. 
stitutes the first record of the presence of the treehopper $U$. crassicornis in Puerto Rico.

Whether the species was accidentally introduced as a stowaway in an airplane arriving on the Island from the mainland or unwittingly brought to the Island in the baggage of a passenger attached to a small infested tree, with eggs already laid under the bark of the twigs, is not known and probably will never be. The facts are: The insect was first noticed breeding on trees on the Island during May 1972, it already is established here, and it probably was introduced in late 1971 or early 1972 close to the time of its detection.

Umbonia crassicornis is a most interesting species. It exhibits such a marked sexual dimorphism, males and females are so different in appearance, and variations within the same sex are so striking, that many scientists have been confused to the point of describing it under a number of different names since 1843 when the French scientists, C.J.B. Amyot and J.G.A. Scrville, described it (1) as Physoplia crassicornis. In 1846, lairmaire described it (2) as Umbonia nigrala. It has been described since under a considerable number of specific names, now in synonymy, by different entomologists. A few recorded by Metcalf and Wade (7) are: Physoplia crassicornis, $P$. nigrata, $P$. media, $P$. peracea; Umbonia nigrata, $U$. orozimbo, $U$. orizimbo, $U$. intermedia, $U$. rectispina, $U$. peracea, $U$. camerani, $U$. pyramidalis, $U$. reducta, and $U$. orizabae.

Umbonia crassicomis is a native of Mexico, Central America, and South America as far south as Ecuador on the west coast and Brazil on the east coast. It also has been recorded from the U.S. (Ohio, South Carolina and Florida), where it probably was introduced many years ago. Butcher (3) collected specimens in April 1951 in the Miami area where a heavy outbreak of the pest occurred during the fall of that year. A similar outbreak in the Panama Canal Zone had been reported previously by Goding in 1921 (4).

\section{HOST PLANTS}

According to Butcher (3), Umbonia has been found on the following host plants in Florida: Pithecellobium dulce (favorite host tree); wild tamarind, Lysiloma bahaminensis; calliandra, Calliandra surinamensis; woman's tongue, Albizzia lebbeck; tamarind, Tamarindus indica; and ('assia sp. Kuitert (6) adds the following hosts: "royal poincinana, acacia and mimosa." An unusual Florida record was established when its nymphal stages were independently recorded on Casuarina sp. by Dr. H. F. Strohecker of the Zoology Department and by Mr. S. Goldweber of the Experimental Farm staff of the University of Florida. Still more peculiar is the record on 
Citrus by Ritcher in Colombia (9), without specifying whether the insect was breeding or just sitting on the tree.

During December 1972, the authors recorded heavy infestations in the Hato Rey area (between Río Piedras and Santurce) on: Pithecellobium dulce; woman's tongue, Albizzia lebbeck; tall albizzia, Albizzia procera; rain tree, Pithecellobium saman and lighter infestations on Barbados pride, Poinciana pulcherrima; tamarind, Tamarindus indica; powder puff, Calliandra surinamensis; yellow cassia, Cassia glauca; pigeonpea, Cajanus indicus, and "guamá," Inga vera. At Isabela, in the northwest corner of the Island, it has been found breeding on "cojóbana," Pithecellobium arboreum. Thus far, 11 host plants have been found infested by Umbonia in Puerto Rico.

In Florida, the common name for this membracid is "thornbug." In Puerto Rico, it is known as the "chinche espinosa." The names in both instances make reference to the spiny pronotal process of the females. The males have a long, thickened, horn-like projection with a blunt end on the pronotum which is totally different from that of females.

\section{BIOLOGICAL NOTES}

The biology of this insect species has not been studied locally thus far. In Florida, Butcher (3) says the development of the immature stages is confined to the woody portions of the host. The eggs are deposited in small masses just under the tender bark of the twigs. Observations of light infestations revealed that egg-laying females remain with their egg masses throughout the 10 to 12 days of incubation. Five nymphal stages have been recognized.

\section{DESCIRIPTION ('F 'THE ADULT}

It is exceedingly difficult to furnish an accurate description of the typical species because of its extraordinary variability, particularly the continental forms, because it can easily be confused with similar species of the genus. However, it can be readily distinguished from other Puerto Rican membracids, first, because it presently is our largest treehopper and sccond, because no other known membracid is so conspicuously green.

The description given by Fowler (5) for Umbonia orozimbo Fairmaire, a synonym, fits the species woll: "The ordinary colour of the females is greenish with yellowish or yellowish-red stripes, but the colour is variable, some being yellowish with dark red stripes like $U$. ataliba, and others, again, reddish-brown or olivaceous; the males vary from a ycllowish or olivaceous tint to almost black; in the varieties with strongly thickened horns the latter are always dark. In all specimens, both male and female, the lines on 
the metopidium have a tendency to run one into the other, and this serves as a rough character for distinguishing the species."

The females are about 1/2-inch long and about the same in height to the very fine point of the pronotal spine. The males are slightly smaller, about $7 / 16^{-i n c h}$ long and from $1 / 2$ - to $9 / 16$-inch in height, to the tip of the blunt pronotal horn (fig. 1).

\section{ECONOMIC IMPORTANCE}

Damage caused by this sucking membracid to host trees in Puerto Rico has been limited thus far to loss of foliage and death of twigs and branches when under heavy infestation. Death of even small trees has not been seen. The pest has been recorded locally on 11 different host trees, all of them
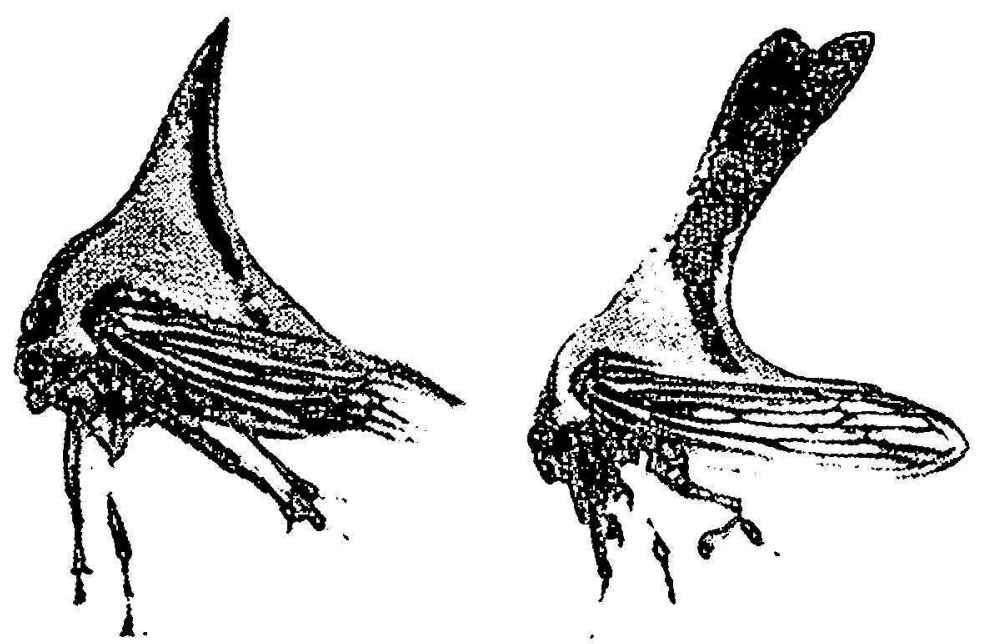

Fig. 1.-Left, female adult of the thornbug or "chinche espinosa," Umbonia crassicornis (Amyot \& Serville). Right, male adult. (After Villalobos.)

more or less ornamental, except pigeonpea which is an economic crop and "guamá" which is generally considered a shade tree for coffee.

This insect species, aside from its potential as an economic pest, is a real nuisance for several reasons. First, the spinal pronotal process of the females is very troublesome to barefooted persons walling on lawns, patios, sidewalks or similar places when nearby trees are heavily infested by the membracid. Second, the nymphs secrete honeydew, a sticky, sugary substance that drops on the foliage of host trees as well as on ornamental plantings below, which serves as a media for the growth of sooty moulds that turn the foliage of affected plants black. Third, a distinctive unpleasant odor can be detected in heavily infested areas, produced possibly by the constant flow of honeydew dropping to the ground.

Butcher (8) states that parasites and predators of this treehopper were conspicuously absent in Florida during his observations. Only one instance 
of predatism was noted; by the pentatomid Euthyrhynchus floridanus (L.). Predators and parasites have not been noted in Puerto Rico thus far.

Laboratory and field tests conducted by the junior author have demonstrated the effectiveness of a number of insecticides which can be applied for the control of both nymphs and adults of Umbonia.

Anyone of the following insecticides ${ }^{3}$ applied at the specified rates, mixed in 100 gallons of water, may be sprayed on infested trees: Diazinon AG-500, 1 pint; Spectracide, 2 pints; Sevin 80, 1 pound; Malathion $57 \%$ EC., 2

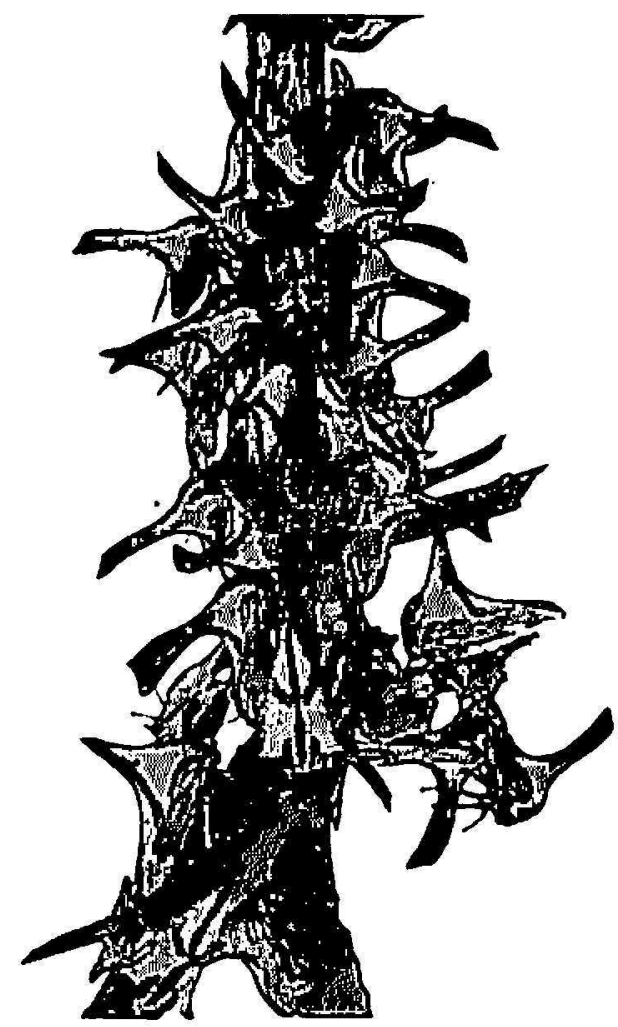

FIg. 2.-Treehopper or thornbug, Umbonia crassicornis (Amyot \& Serville), infesting a Pilhecellobium twig. (From: Bull. 595, Florida Agr. Exp. Sta.)

pints; Isotox Garden Spray, 3 pints; Endosulfan, 2 pounds. Among the insecticides mentioned, the last proved least effective.

\section{SUMMARY}

Umbonia crassicornis Amyot \& Serville, a continental tropical American treehopper or membracid, probably was introduced accidentally into Puerto Rico from the mainland. The manner of introduction is not known,

${ }_{3}^{3}$ Trade or other names of insecticides are used in this publication solely for the purpose of providing specific information. Mention of trade or other names of insecticides does not constitute a guarantee or warranty of the product by the Agricultural Experiment Station of the University of Puerto Rico, or an endorsement over other products not mentioned. 
but possibly either with infested plant material hidden in passenger baggage or as a fertile female hitchhiker in an airplane arriving at San Juan from the U.S. where it apparently found suitable breeding conditions in the vicinity of the Isla Verde International Airport.

This treehopper mainly attacks leguminous trees. It was seen first in the Santurce area of San Juan, in May 1972, attacking its favorite host, Pithecellobium dulce trees. It since has spread throughout several towns in the interior of the Island, and along the north and west coast as far as Mayagüez. It has been recorded locally thus far on 11 different host trees.

Umbonia is considered to be a pest of ornamental trees and thus is of cconomic importance. Although it has not killed trees thus far in Puerto Rico, it has affected their appearance by destroying many of their twigs and branches. When massive infestations occur, adults of both sexes and their nymphal stages are present by the thousands on the branches of the trees. The insect secretes honeydew, a sugary substance favorable to the growth of sooty-molds. These fungal growths cause blackening of foliage of plants upon which the honeydew falls.

The female has a long pointed spinal process on the pronotum. This horny, splinter-like protuberance is a nuisance for barefooted peoplc, as well as for those who catch the insect inadvertently.

These trechoppers can be controlled by periodic spray applications of any one of the following insecticides: Diazinon AG-500, Spectracide, Sevin 80, Malathion $57 \%$, Isotox Garden Spray, and Endosulfan.

\section{RESUMEN}

Un membrácido o saltón de los árboles, Umbonia crassicornis Amyot \& Serville, nativo de la América continental tropical, probablemente se introdujo accidentalmente en Puerto Rico. Se desconoce si e' insecto llegó a la Isla con el equipaje de algún pasajero en material vegetativo infestado o si alguna hembra fértil entró como polizón a bordo de un avión que partiera del continente. De ser así, es probable que una vez aquí voló fuera del avión, para encontrar en las cercanías del Aeropuerto Internacional de Isla Verde árboles hospedadores tropicales propicios para su propagación.

El insecto se caracteriza por un dimorfismo sexual, esto es, la hembra difiere del macho morfológicamente. Debido a esa característica, originalmente los taxónomos describieron la especie dándole diferentes nombres científicos.

El saltón ataca principalmente los árboles de la familia de las leguminosas. Se observó por primera vez en mayo de 1972, en la zona de Santurce en San Juan, atacando árboles de Pilhecellobium dulce, su hospedador favorito. Desde entonces la especie se ha propagado por toda el Ārea Metropolitana de San Juan hasta llegar a algunos de los pueblos del interior de la Isla y a otros de las costas norte y occidental hasta Mayagüez. Hasta la fecha, se ha informado localmente en 11 especies diferentes de árboles.

Umbonia se considera como una plaga de árboles ornamentales por cuya razón tiene gran importancia económica Aunque no destruye los árboles por completo, sí 
afecta grandemente las ramas atacadas. Las infestaciones causadas por Umbonia son masivas y cuando ocurren se ven miles de adultos y ninfas en el ramaje de los árboles atacados. El membrácido segrega un líquido azucarado que propicia el desarrollo de los hongos de la fumagina, que tornan negro el follaje.

La hembra tiene una aguda espina en el pronoto, con la cual puede hincar a las personas descalzas y a las que se descuidan al coger el insecto.

Este saltón puede combatirse con aspersiones periódicas de cualquiera de los insecticidas siguientes: Diazinon AG-500, Spectracide, Sevin 80 , Malathion $57^{\circ}$; , Isotox Garden Spray y Indosulfan.

\section{LITERATURE CITED}

1. Amyot, C. J. B., and Serville, J. G. A., Deuxieme Partie. Homopteres. Homoptera Latr. Hist. Nat. des Insectes Hémiptères, 1- $6 \mathbf{i} 6,1843$.

2. Fairmaire, L. M. H., Revue de la tribu des membracides, Ann. Soc. Entomol. France (2) 4: 235-320, 1846.

3. Butcher, F. G., Unusual abundance of the treehopper Umbonia crassicornis A. \& S., The Florida lintomol. 36 (2): 57-9, June 1953.

4. Goding, F. W., An injurious membracid, J.N.Y. Entomol. Soc. 38 (1): $47,1930$.

5. Fowler, W. W., Biologica Centrali-Americana. Insecta-Rhynchota-IemipteraHomoptera Vol. II, Part I, pp. 36-7, 189t-1909.

6. Kuitert, L. C., Insect pests of ornamental plants, Florida Agr. Exp. Sta., Bull. 595, 1-50, April 1958.

7. Metcalf, Z. P., and Wade, V., General Catalogue of the Homoptera. Suppl. to Fascicle I-Membracoidea-Section I, 542-6, 1965.

8. Ramos, J. A., Personal communication, Mayagüez, P. R., Nov. 14, 1972.

9. Ritcher, L., Catálogo de los membrácidos de Colombia, Rev. Acad. Colombiana de Ciencias Exactas, Físicas y Naturales 4: 405-9, 1942. 